\begin{tabular}{|c|c|c|}
\hline Beitr. Ent. & Keltern & ISSN 0005-805X \\
\hline $\mathbf{5 5}(2005) 2$ & S. $271-277$ & 27.12 .2005 \\
\hline
\end{tabular}

\title{
The sawfly genus Amauronematus in Corsica, with a new species of the subgenus Brachycoluma
}

\section{(Hymenoptera, Tenthredinidae)}

\author{
With 15 figures
}

ANDREw D. Liston

\section{Zusammenfassung}

Die überwiegend in borealen Regionen vorkommenden Arten der Blattwespengattung Amauronematus wurden bisher selten im Mittelmeerraum nachgewiesen. In der vorliegenden Arbeit werden Amauronematus (Brachycoluma) spaethi sp. n. und A. (A.). sp. near histrio (SERville, 1823) aus Korsika gemeldet. Die imaginale Morphologie der neuen Art wird mit $A$. viduatus (Zetтerstedt, 1838) verglichen. Wirtspflanze von A. spaethi ist Salix atrocinerea.

\section{Summary}

The predominantly boreal sawfly genus Amauronematus is seldom recorded in the Mediterranean Region. Amauronematus (Brachycoluma) spaethi sp. n. and A. (A.) sp. near histrio (SERville, 1823) are here recorded from Corsica. Imaginal morphology of $A$. spaethi sp. n. is compared with A. viduatus (ZetTERstedT, 1838). Hostplant of the new species is Salix atrocinerea.

\section{Keywords}

Taxonomy, distribution, Amauronematus, Brachycoluma, Corsica, Salix

\section{Introduction}

In the spring of 2004 J. SpÄTH and the author collected sawflies in Corsica (LisTON \& SpÄтн 2005). Material included larvae of some unidentified Amauronematus Konow, 1890 species. Specimens reared from these, belonging to two species, have now been examined. One is a previously undescribed species of the subgenus Brachycoluma STRAND, 1929 (= Decanematus Malaise, 1931). Brachycoluma, often referred to in the older literature as the Amauronematus viduatus species-group, is regarded by some specialists as a separate genus (WONG 1968, LACOURT 1999). Imagines considerably resemble superficially some species of Pontania A. Costa, 1852 and are often misidentified as such because of their shared small body size, generally dark colour and exclusive association with Salix. Brachycoluma species are amongst the very first sawflies to appear in spring: as early as late March in Central Europe. The young larvae are endophytic, living in the opening buds and between clusters of young leaves, whereas the last instar feeds externally on the 
leaves (Zinovjev \& Vikberg 1998). Larvae of subgenus Amauronematus either develop at first in the catkins and later as free-feeders on the leaves (e. g. A. histrio species-group), or they feed exophytically on the leaves immediately after leaving the egg (Zinovjev \& VIKBERG 1998). Thirteen Brachycoluma species have been previously described, concentrated in the boreal regions of the Holarctic (TAEger \& Blank 2005). Brachycoluma, like Amauronematus subgenus Pontopristia (larvae endophytic in Salix catkins), are as far as is known attached exclusively to Salix, whilst Amauronematus s. str. are predominantly attached to Salix but a few species also feed on Vaccinium, Betula, and Populus (Schmidt 1997, LACOURT 1999).

\section{Amauronematus (Brachycoluma) spaethi sp. n.}

Length: $4.5-5.0 \mathrm{~mm}$.

\section{Female:}

Whole insect (Figs $1 \& 2$ ). Head and body, including abdominal tergites, with dense, short, pale pubescence. Head subparallel behind eyes in dorsal view. Clypeus with shallow medial excision (Fig. 3). Postocellar area with a medial furrow which reaches completely from front to rear (Figs $3 \& 5$ ). Head, mesonotum and scutellum dull with dense sculpture. Mesopleura shining between pubescence. Malar space 0.65 of distance between antennal sockets. Antenna slightly shorter than costa (0.9:1.0). Medial division of front mesonotal lobes weak anteriorly, obsolete posteriorly. Hind tarsus almost as long as hind tibia (0.9:1.0). Apical half of tibia and whole tarsus of all legs laterally compressed (Fig. 4), broadest point of hind tibia in lateral view 1.5 times its apical width in dorsal view. Basitarsus in lateral view only 3.0-3.5 times as long as its apical width. Tarsomere 2 in lateral view 1.8-2.0 times as long as broad. Tibial spurs short and rather thick: maximally as long as apical width of tibia in lateral view. Abdominal terga densely sculptured. Ovipositor sheath (valvula 3 + valvifer 2) $0.8-0.85$ times as long as rear tibia. Valvula 3 1.05-1.10 times longer than valvifer 2. Valvula 3 1.55-1.70 times as long as tarsomere 1 of hind leg, in dorsal view subtriangular (Fig. 6), projecting slightly beyond cerci; apex in lateral view acute (Fig. 7), tapering gently; longest setae arising most basally, apically more or less bent inwards, about two-thirds as long as a cercus, concentrated on apical half of sheath, forming an acute angle in dorsal view. Lancet (Fig. 8) evenly curved throughout its length, gently tapering; 22-23 annulets, serrulae on apical 11 , and a very inconspicuous small tooth on basal annulet; covered with evenly distributed setae, all sutures with small, regular ctenidia, but present only on dorsal parts of 3 basal sutures. Hypopygium broadly excised each side of large, rounded medial projection.

Colour: head pale brown. Black are antennae (entirely), tips of mandibles, small area around dorsal tentorial pit and below antenna, a separate patch surrounding ocelli extending backwards through middle of the postocellar area, lateral postocellar furrows and entire occiput. Thorax black. Yellow-brown are tegulae and pronotum except for anterior extremity of latter, edges of median mesonotal lobe, spots on anterior lateral margins of scutellum, upper half of mesepisternum. Basal half of coxa blackened, apically pale. Trochanters entirely pale. Femora dorsally pale with black underside and a small spot above on extreme apex. Tibiae with outer edge broadly fuscous (most pronounced 
on hind legs), only extreme base completely pale. Tarsi almost completely black, but obscurely paler on underside of basitarsus. Stigma blackened at edges, white in centre and at base. Apical half of costa dark, basally pale. Rest of venation dark. Dorsal parts of abdominal terga 1-7 black. Base of tergum 8 narrowly brown, rest black. Tergum 10 with narrow black medial stripe. Valvula 3 of ovipositor sheath entirely and extreme base of valvifer 2 black. Remainder of abdomen pale yellow-brown.

Variability: extent of black on thorax varies slightly, so that rear femora may be completely black basally, and anterior upper edge of mesepisternum, epicnemium and postspircular tergite may be either almost completely yellow, or mostly black. Depressed medial area on postocellar area is always present, but in one paratype much narrower than the other specimens.

Male: unknown.

Holotype: female, Corsica "SW Porto Vecchio, Tamaricciu-Tal [Valley], Corse du Sud, 20 m [altitude], Larven an Salix cinerea [actually atrocinerea], 07.iv.2004, em. iv.2005, leg. J. Sрётн”. Deposited in Deutsches Entomologisches Institut, Müncheberg (DEI).

Paratypes: 1 ㅇ, same data as holotype, coll. J. SPÄTH, DEI; 2 ㅇ 우, Foret dom. Vivario, 900 m, from larvae on Salix atrocinerea, 09.v.2004, emerged iv.2005 leg. A. D. Liston, coll. DEI.

Etymology: species name is dedicated to Dr. Jochen SpäTH (Dingolfing).

\section{Hostplants: Salix atrocinerea.}

Habitat: along the edges of natural watercourses, drainage ditches.

Larva: young larva grass-green, head paler with an obscure brown tint on frons, setae arising from black spots (Fig. 14). Mature larva with two pairs of darker green subdorsal and suprapedal stripes, setae arising from dark green spots, head as dark as body (Fig. 15), full-grown length $18 \mathrm{~mm}$.

Biology: according to observations made by J. SPÄTH, early instars live in a shelter consisting of two to four leaves at the apex of a side-shoot. The apex of the shoot is consumed first, with the result that the internodes of the apical leaves do not lengthen. Although these leaves continue to grow, they fail to separate from each other and thus remain clustered around the larva and the damaged shoot apex. The larva feeds first on the innermost leaves, then the outer ones. The stage of development at which transition takes place to free-feeding on the leaf edges outside the shelter appears to be somewhat variable. Larvae only $6 \mathrm{~mm}$ long were found feeding on the outside leaves of their shelters, leaving these through a small hole which is also used for the ejection of excrement. Often, the consumption of the outermost leaves results in a longitudinal opening, revealing the interior of the shelter (as in Fig. 14). At least the last instar is entirely exophytic.

Cocoon: formed in the ground. A thick, single-walled construction, of pale brown colour. The larvae were given river sand as an overwintering medium. Grains of this were spun into the surface of the cocoon. 


\section{Distribution:}

Corsica. Larvae thought to belong to this species were collected at various localities between sea-level and $900 \mathrm{~m}$ (Liston \& SPÄTH 2005). The hostplant is widely distributed in Corsica and the collecting localities of the types $60 \mathrm{~km}$ apart. A. spaethi seems therefore to be a widespread species in Corsica.

\section{Identification:}

Palaearctic species of Amauronematus (Brachycoluma) were keyed by Zhelochovtsev (1988). A. spaethi runs to A. viduatus (Zetterstedt, 1838) in this key, with a difficulty at couplet 5(4) because $A$. spaethi has entirely dull mesonotal lobes. At least the lateral mesonotal lobes of $A$. viduatus are less densely sculptured than $A$. spaethi, and therefore somewhat shining. The alternative couplet, leading only to A. malaisei Hellén, is inappropriate because in $A$. malaise $i$ the ovipositor sheath is as long as the rear tibia and in $A$. spaethi markedly shorter. Several characters distinguish $A$. spaethi from the others previously described: clypeus with a shallow medial excision (compare Figs $3 \& 10$ ), postocellar area with medial depression developed continuously from front to rear (Figs $3 \& 5$ ) (at most the anterior part depressed in others, never channelled right through, Figs 10 $\& 11$ ), and most clearly by the strongly laterally compressed tarsi: tarsomere 2 in lateral view maximally twice as long as apical width, Fig. 4 (tarsi in other species subcylindrical, tarsomere 2 at least $3 \mathrm{x}$ as long as maximal width, Fig. 12). The black-lined outer surface of the tibiae seems to be peculiar to A. spaethi. The lancet of the new species (Fig. 8) is similar to that of $A$. viduatus (Fig. 13), but slightly broader, with a single minute tooth on the basal annulet whereas viduatus has two such teeth (the basal one larger than in $A$. spaethi) and the basal suture in $A$. spaethi more curved with the upper part less oblique. Ratio of lengths of valvula 3 / valvifer 2 of ovipositor sheath is also diagnostic: 1.20-1.25 (viduatus), 1.05-1.10 (spaethi). The body of $A$. spaethi (Fig. 1) in dorsal aspect is less elongate than $A$. viduatus (Fig. 9). Body length of the types of $A$. spaethi $(4.5-5.0 \mathrm{~mm}$ ) is less than female specimens of $A$. viduatus examined $(5.0-6.0 \mathrm{~mm})$, but this could be because the former were stunted by adverse rearing conditions. In lowland Central European specimens of $A$. viduatus the body colour is variable (ENSLIN 1915, BENSON 1958) and may be extensively pale as in $A$. spaethi, but in these pale specimens of $A$. viduatus the legs are also almost entirely pale.

\section{Amauronematus (Amauronematus) sp. near histrio (SERVILLE, 1823)}

Corsica: 1 으, Aléria, 30 m. above sea-level, 07.v.2004, ex larva, Salix alba, leg. Liston, DEI (Liston \& SpäTh 2005).

The larva made a soft, whitish cocoon of loose fibres on the upper interior of the rearing container and later pupated. The adult died in the cocoon in March 2005 with wings unexpanded but body pigmentation fully developed. Habitus and colour pattern correspond very closely with Central European specimens of $A$. histrio. TAEger et al. (1998) following SснміDт (1997) exclude Salix alba and fragilis from the list of hosts of $A$. histrio, stating that the records from these willows for $A$. histrio by BENSON (1958) appear to refer to another species of this group. The identification of the Corsican specimen must therefore await further revisionary work. 


\section{Discussion}

The genus Amauronematus is species rich in boreal and montane regions of Europe, with more than one hundred and twenty described species in the West Palaearctic (Lacourt 1999, TAeger \& Blank 2005). Very few records exist for the Mediterranean Region, but this may merely reflect the lack of appropriate collecting techniques. In Corsica at least one other species is suspected to be present: larvae of Amauronematus subgenus Brachycoluma were found on Salix purpurea, differing in colouration from those of $A$. spaethi. The former have not been reared to adult.

Two species of subgenus Brachycoluma of Amauronematus are at present regarded to be oligophagous on Salix: A. leucolenus (ZADDACH, 1883) and A. viduatus (Benson 1958, LACOURT 1999). Considering the narrow hostplant range of species of the genus Amauronematus s. 1., this needs further investigation. No host plant data are available for other described Brachycoluma taxa. It is possible that more than one species is at present confused under the name $A$. viduatus and that these tend more to monophagy than previously thought. Zinovjev \& Vikberg (1998) suggest that $A$. viduatus in Northern Europe is typically associated with Salix myrsinifolia (= nigricans).

\section{Acknowledgements}

Christian Kutzscher (Müncheberg, Germany) assisted with preparation of the illustrations. Frank Burger (Weimar, Germany) and Dr. Jochen Späth (Dingolfing, Germany) loaned material. Dr. Stephan M. Blank (Müncheberg) is warmly thanked for suggestions and improvements concerning the manuscript.

\section{References}

Benson, R. B. 1958: Hymenoptera (Symphyta). - Handbooks for the Identification of British Insects, London 6 (2c): 139-252.

Ensuin, E. 1915: Die Tenthredinoidea Mitteleuropas. IV. - Deutsche Entomologische Zeitschrift, Berlin, Beiheft 4: 311-412.

LACOURT, J. 1999: Répertoire des Tenthredinidae ouest-paléarctiques (Hymenoptera, Symphyta). - Mémoires de la Société Entomologique de France, Paris 3: 1-432.

Liston, A. D. \& Sрётн, J. 2005: New data on the sawfly fauna of Corsica with the description of a new species Pontania cyrnea sp. n. - Nachrichtenblatt der bayerischen Entomologen, Munich 54 (1-2): 2-7.

Schmidt, S. 1997: Amauronematus Konow, 1890 - Ökologie und Taxonomie der nordeuropäischen Arten des fallax-Komplexes (Hymenoptera, Tenthredinidae). - Beiträge zur Entomologie, Berlin 47 (2): 227-326.

Taeger, A.; Altenhofer, E.; Blank, S. M.; Jansen, E.; Kraus, M.; Pschorn-Walcher, H. \& Ritzau, C. 1998: Kommentare zur Biologie, Verbreitung und Gefährdung der Pflanzenwespen Deutschlands (Hymenoptera, Symphyta). - In: Taeger, A. \& Blank, S. M. (eds.) Pflanzenwespen Deutschlands (Hymenoptera, Symphyta). Kommentierte Bestandsaufnahme. - Goecke \& Evers, Keltern: pp.49-136.

Taeger, A. \& Blank, S. M. 2005: ECatSym: Elektronischer Katalog der Symphyta der Welt. Online Version 1.0 (1. September 2005). B http://www.zalf.de/home_zalf/institute/dei/php/ecatsym/ecatsym.php.

Wong, H. R. 1968: Decanematus, a sawfly genus new to North America (Hymenoptera: Tenthredinidae). - Canadian Entomologist, Ottawa 100 (1): 84-88.

Zhelochovtsev, A. N. 1988: Symphyta. - In: Medvedjev, G. S. (ed.): Opredelitel nasekomykh Evropeiskoi Chasti SSSR. III. Pereponchatokrylye. - Nauka, Leningrad 6: 7-234.

Zinovjev, A. G. \& Vikberg, V. 1998: On the biology of Nematinae with hiding larvae (Hymenoptera, Symphyta, Tenthredinidae). - Beiträge zur Entomologie, Berlin 48 (1): 145-155. 


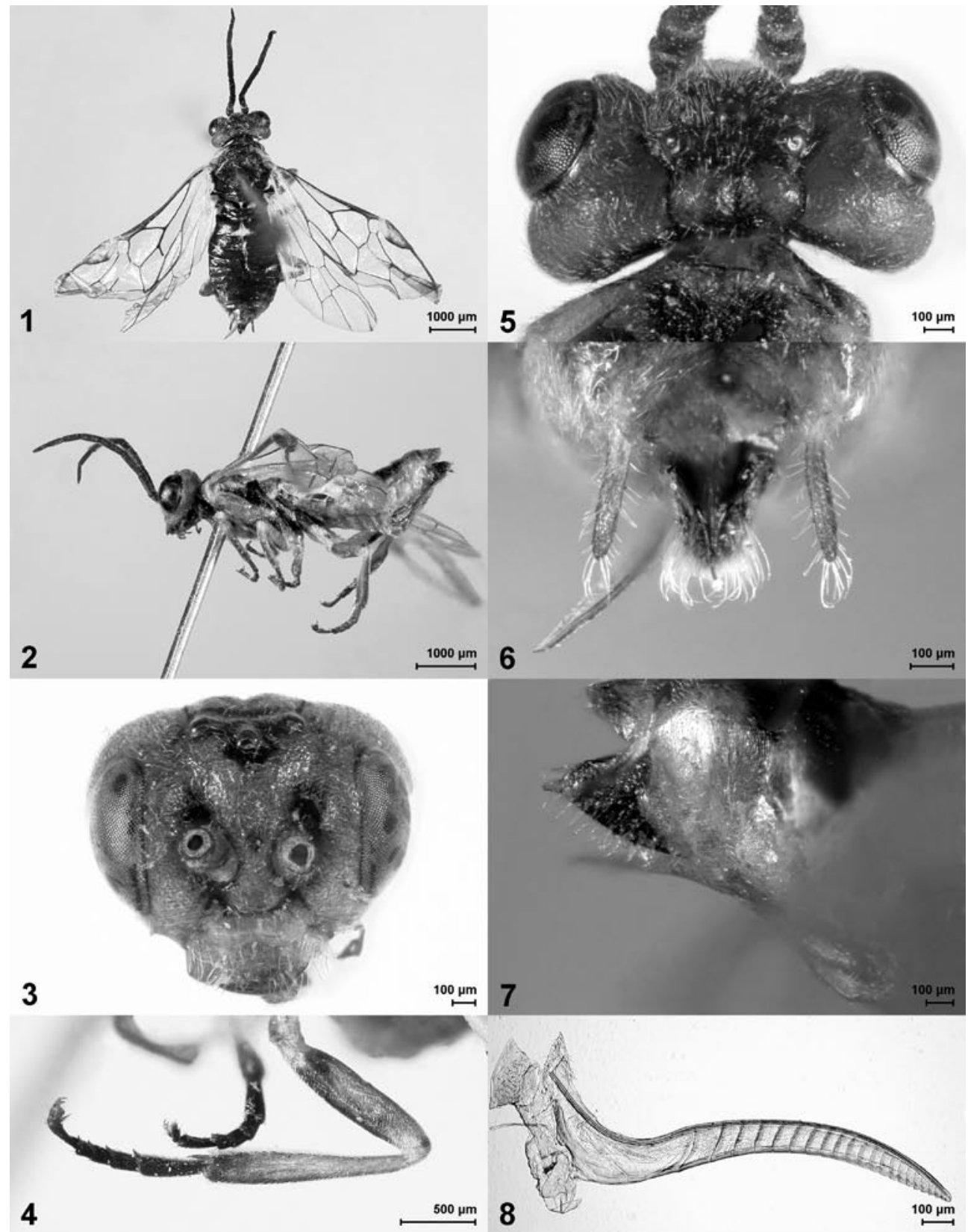

Figs 1-8: Amauronematus (Brachycoluma) spaethi sp. n., female, Corsica (see text). 1; dorsal view. 2; lateral view. 3; head, frontal. 4; rear leg. 5; head, dorsal. 6; sawsheath, dorsal. 7; sawsheath, lateral. 8; lancet. 


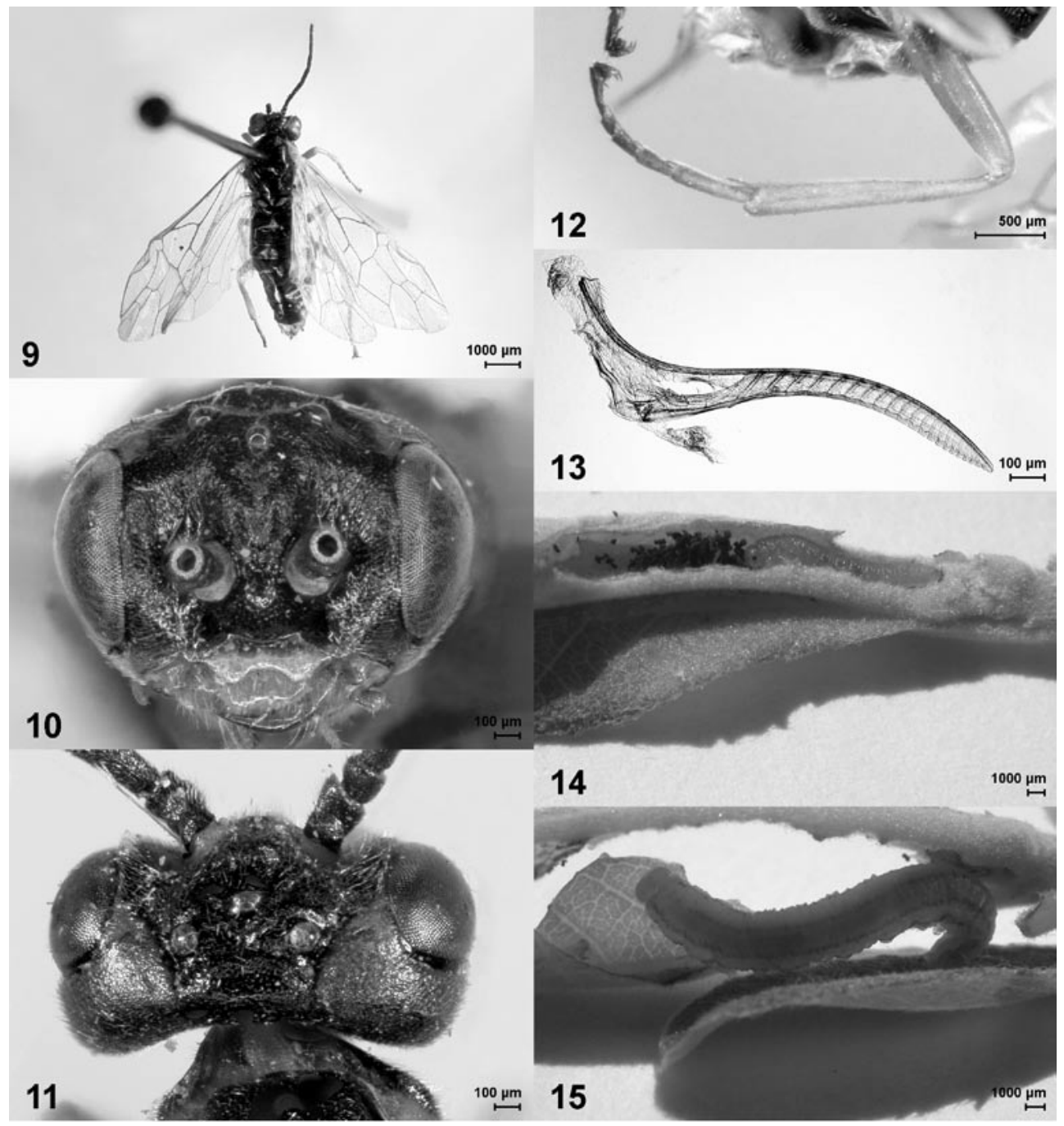

Figs 9-13: Amauronematus viduatus (ZetTERSTEDT), female, Germany, Umg. Oranienburg, NSG Pinnower See, 1.5.1989, leg. J. Oehlke, DEI. 9; dorsal view. 10; head, frontal. 11; head, dorsal. 12; rear leg. 13; lancet. Figs 14-15: A. spaethi sp. n. larva on Salix atrocinerea, photos by J. SРётн. 14; young larva and larval shelter. 15; last instar larva.

\section{Author's address:}

ANDREw D. Liston

Deutsches Entomologisches Institut

Leibniz-Zentrum für Agrarlandschaftsforschung (ZALF)

Eberswalder Strasse 84

D - 15374 Müncheberg

e-mail: liston@ zalf. de 